\title{
Defining T Cell Tissue Residency in Humans: Implications for HIV Pathogenesis and Vaccine Design
}

\author{
Barbara L. Shacklett $^{1,2} \cdot$ April L. Ferre $^{1} \cdot$ Brenna E. Kiniry $^{1}$ \\ Published online: 12 February 2020 \\ (C) The Author(s) 2020
}

\begin{abstract}
Purpose of Review This review summarizes recent literature defining tissue-resident memory $T$ cells $\left(T_{R M}\right)$ and discusses implications for HIV pathogenesis, vaccines, and eradication efforts.

Recent Findings Investigations using animal models and human tissues have identified a $T_{R M}$ transcriptional profile and elucidated signals within the tissue microenvironment leading to $T_{R M}$ development and maintenance. $T_{R M}$ are major contributors to host response in infectious diseases and cancer; in addition, $\mathrm{T}_{\mathrm{RM}}$ contribute to pathogenic inflammation in a variety of settings. Although $\mathrm{T}_{\mathrm{RM}}$ are daunting to study in HIV infection, recent work has helped define their molecular signatures and effector functions and tested strategies for their mobilization.

Summary Exclusive reliance on blood sampling to gain an understanding of host immunity overlooks the contribution of $T_{R M}$, which differ in significant ways from their counterparts in circulation. It is hoped that greater understanding of these cells will lead to novel approaches to prevent and/or eradicate HIV infection.
\end{abstract}

Keywords Tissue $\cdot$ Mucosa $\cdot$ Memory $\cdot$ T cell $\cdot$ CTL

\section{Introduction}

\section{T Cell Biology and the Challenge of "Immune Geography"}

In their quest to eliminate pathogens from the body, antigenspecific lymphocytes face multiple challenges, not the least of which is "immune geography": when infection occurs, a small number of T cells, programmed with TCR specificity for a relevant antigen, must somehow encounter infected cell(s), wherever in the body they might be located. Our contemporary understanding of immune responses is based on pioneering work

This article is part of the Topical Collection on HIV Pathogenesis and Treatment

Barbara L. Shacklett

blshacklett@ucdavis.edu

1 Department of Medical Microbiology and Immunology, School of Medicine, University of California, Davis, CA 95616, USA

2 Division of Infectious Disease, Department of Medicine, School of Medicine, University of California, Davis, CA 95616, USA performed over several decades, which elucidated the trafficking patterns of lymphocytes throughout the body and the critical roles played by secondary lymphoid organs as sites of antigen encounter and presentation (for detailed review, see [1]). In the 1950s and 1960s, investigators used radioactive tracers to follow trafficking of lymph node cell suspensions following injection into blood. This work gave rise to an awareness of the role of lymph nodes in antigen presentation [2]. Some 40 years later, Sallusto and Lanzavecchia advanced a model for T cell differentiation based upon expression patterns of cell surface markers CCR7 and CD45RA [3]. According to this model, $\mathrm{CD}^{+}$and $\mathrm{CD} 8^{+} \mathrm{T}$ cells could be defined as antigen-inexperienced and naive $\left(\mathrm{CD} 45 \mathrm{RA}^{+} / \mathrm{CCR} 7^{+}\right)$or as antigen-experienced memory cells that were either highly proliferative (central memory cells or $\mathrm{T}_{\mathrm{CM}}, \mathrm{CD} 45 \mathrm{RA}^{\text {neg }} / \mathrm{CCR}^{+}$) or optimized for rapid effector function (effector memory cells or $\mathrm{T}_{\mathrm{EM}}, \mathrm{CD} 45 \mathrm{RA}{ }^{\text {neg }} / \mathrm{CCR} 7^{\text {neg }}$ ) [3]. This model, although widely accepted for many years, relied exclusively on characterization of $\mathrm{T}$ cells isolated from blood, which we now know to be significantly different from their counterparts in tissues. T cells localized to nonlymphoid tissues, such as the lung, gut, and reproductive tract, were believed to correspond to $\mathrm{T}_{\mathrm{EM}}$ and were assumed to recirculate to some extent as a means of performing immunosurveillance of these important tissues. However, over the past 10 years, in an 
important paradigm shift, studies in rodents and humans have revealed and confirmed the existence of "tissue-resident" cells, or $\mathrm{T}_{\mathrm{RM}}$, that patrol relatively limited areas within nonlymphoid tissues for signs of infection, without recirculating throughout the body [4-11].

\section{How Are Tissue Resident T Cells Defined?}

Key markers and pathways that characterize tissue resident memory cells have been identified in murine experimental models [1, 12-15] (Table 1). Briefly, $\mathrm{T}_{\mathrm{RM}}$ are thought to derive from effector $\mathrm{T}$ cells, which develop distinctive transcriptional programs and phenotypic characteristics following migration to peripheral tissues. Once localized to these tissues, they are exposed to locally produced cytokines, including transforming growth factor beta (TGF- $\beta$ ), as well as IL-15, IL-33, and TNF- $\alpha$ [28]. TGF- $\beta$ promotes expression of $\alpha \mathrm{E}(\mathrm{CD} 103) \beta_{7}$, an integrin whose ligand, E-cadherin, is expressed by epithelial cells in the skin, gut, and other tissues. Interaction between CD103 and E-cadherin helps retain $\mathrm{T}_{\mathrm{RM}}$ in these tissues. Intriguingly, at a much earlier stage, during homeostatic encounters that occur between resting naïve $\mathrm{T}$ cells and migratory dendritic cells within lymphoid tissues, TGF- $\beta$ is believed to play a role in "pre-conditioning" the naïve $\mathrm{T}$ cells that will eventually become tissue residents [29•].
The markers CD69 and CD103 are most commonly used to quantify $\mathrm{T}_{\mathrm{RM}}$; however, neither marker is perfectly correlated with tissue residency $[1,16,17]$. CD103 is primarily associated with $\mathrm{CD}^{+}$, rather than $\mathrm{CD} 4^{+} \mathrm{T}_{\mathrm{RM}}$. $\mathrm{CD} 69$ is transiently expressed following TCR activation, including by recirculating $T$ cells, leading to potential confusion. $T_{R M}$ lack expression of sphingosine-1-phosphate receptor S1PR1 (also referred to as $\mathrm{S}_{1} \mathrm{P}_{1}$ ), which mediates tissue egress in response to its ligand, sphingosine-1-phosphate (S1P). CD69 associates with and inhibits the function of S1PR1, thereby blocking cell egress [19]. In addition, expression of transcription factor $\mathrm{KLF} 2$, which is required for S1PR1 expression, is downregulated in $\mathrm{T}_{\mathrm{RM}}$. Other transcription factors downregulated in $\mathrm{T}_{\mathrm{RM}}$ cells are Eomesodermin and T-bet; their expression suppresses $T_{R M}$ differentiation [20]. In murine $T_{R M}$, Hobit and Blimp1 are proposed as central transcriptional regulators of $T_{R M}$ tissue retention [21]. A core transcriptional signature for human $T_{R M}$ has been reported and includes numerous markers similar to those identified in mice $[18 \cdot \bullet]$. However, multiple studies have failed to implicate Hobit in the core signature for human $\mathrm{T}_{\mathrm{RM}}[18 \cdot \bullet, 21]$.

Phenotypically, $\mathrm{T}_{\mathrm{RM}}$ are somewhat heterogeneous, with some described as resembling hematopoietic stem cells (HSC) in their ability to efflux small molecules such as fluorescent mitochondrial dyes [30•]. These "efflux $(+)^{\prime} \mathrm{T}_{\mathrm{RM}}$ exhibit reduced turnover and increased proliferative capacity

Table 1 Factors associated with $\mathrm{T}_{\mathrm{RM}}$ development and maintenance. Factors are listed by their order of appearance in the text

\begin{tabular}{|c|c|c|c|}
\hline Factor & Expression & Function & References \\
\hline CD103 & $\begin{array}{l}\text { Expressed mainly on } \mathrm{CD}^{+} \mathrm{T}_{\mathrm{RM}} \text { in certain } \\
\text { tissues (e.g., gut) }\end{array}$ & $\begin{array}{l}\text { Interacts with E-cadherin, tethering } \mathrm{CD}^{+} \mathrm{T}_{\mathrm{RM}} \text { to } \\
\text { epithelial cells }\end{array}$ & {$[1,16,17]$} \\
\hline CD69 & Expressed on most, but not all $\mathrm{T}_{\mathrm{RM}}$ & $\begin{array}{l}\text { Associates with and inhibits S1PR1, blocking tissue } \\
\text { egress }\end{array}$ & {$[1,16,17]$} \\
\hline KLF2 & Downregulated in $\mathrm{T}_{\mathrm{RM}}$ & Transcription factor required for S1PR1 expression & {$[1,18 \bullet \bullet]$} \\
\hline S1PR1 & Downregulated in $\mathrm{T}_{\mathrm{RM}}$ & Mediates tissue egress in response to its ligand, S1P & {$[1,19]$} \\
\hline T-bet & Downregulated in $\mathrm{T}_{\mathrm{RM}}$ & Transcription factor that suppresses $\mathrm{T}_{\mathrm{RM}}$ differentiation & {$[18 \bullet \bullet, 20]$} \\
\hline Eomesodermin & Downregulated in $\mathrm{T}_{\mathrm{RM}}$ & Transcription factor that suppresses $\mathrm{T}_{\mathrm{RM}}$ differentiation & {$[18 \bullet \bullet, 20]$} \\
\hline Hobit & $\begin{array}{l}\text { Upregulated in mouse but apparently not } \\
\text { human } T_{R M}\end{array}$ & Suppresses KLF2, central regulator of mouse $\mathrm{T}_{\mathrm{RM}}$ & {$[18 \bullet \bullet, 21]$} \\
\hline Blimp-1 & Collaborates with Hobit in mouse $\mathrm{T}_{\mathrm{RM}}$ & Central regulator of mouse $\mathrm{T}_{\mathrm{RM}}$ & {$[18 \bullet \bullet, 21]$} \\
\hline mTOR kinase & $\begin{array}{l}\text { Expression may be required for accumulation } \\
\text { of mouse } T_{R M}\end{array}$ & Regulator of cell differentiation and survival & {$[22,23]$} \\
\hline FABP4, FABP5 & $\begin{array}{l}\text { Required for long-term survival of } \mathrm{T}_{\mathrm{RM}} \text { in } \\
\text { mouse skin }\end{array}$ & $\begin{array}{l}\text { Fatty acid binding proteins, promote lipid uptake and } \\
\text { transport }\end{array}$ & {$[24 \bullet]$} \\
\hline Runx3 & $\begin{array}{l}\text { Promotes mouse } \mathrm{T}_{\mathrm{RM}} \text { differentiation and } \\
\text { maintenance }\end{array}$ & $\begin{array}{l}\text { Transcription factor that regulates tissue-residency in } \\
\text { multiple cell types }\end{array}$ & {$[15,25 \cdot]$} \\
\hline $\mathrm{P} 2 \mathrm{RX} 7$ & Supports long-lived $\mathrm{T}_{\mathrm{RM}}$ & $\begin{array}{l}\text { Sensor for extracellular ATP; detects injury and } \\
\text { inflammation }\end{array}$ & {$[26 \bullet]$} \\
\hline Bhlhe40 & $\begin{array}{l}\text { Required for development and } \\
\text { polyfunctionality of } \mathrm{CD} 8^{+} \mathrm{T}_{\mathrm{RM}} \text { and TIL }\end{array}$ & $\begin{array}{l}\text { Transcription factor; programs mitochondrial metabolism } \\
\text { and active chromatin state }\end{array}$ & {$[27 \bullet]$} \\
\hline
\end{tabular}

$C D$ cluster of differentiation, KLF2 Krüppel-like Factor 2, S1PR1 sphingosine-1-phosphate receptor 1, T-bet T-box transcription factor expressed in T cells, Hobit Homolog of Blimp-1 in T cells, Blimp-1 B lymphocyte maturation promoting transcription factor-1, $m$ TOR mammalian target of rapamycin, $F A B P$ fatty acid binding protein, Runx3 Runt-related transcription factor $3, P 2 R X 7$ purinergic receptor P2X7, Bhlhe40 Basic helix-loop-helix family member E40 
relative to efflux-negative $T_{R M}$. Upon stimulation, efflux $(+)$ $\mathrm{T}_{\mathrm{RM}}$ show increased production of IL-17 compared to efflux (-) $\mathrm{T}_{\mathrm{RM}}$, suggesting a potential role in IL-17-mediated inflammatory diseases. In contrast, efflux(-) $\mathrm{T}_{\mathrm{RM}}$ produced higher levels of TNF- $\alpha$, IFN- $\gamma$, IL-2, and IL-4 in response to stimulation $\left[30^{\bullet}\right]$.

A recent study of $\mathrm{CD} 4^{+} \mathrm{T}_{\mathrm{RM}}$ in skin explants from healthy human donors revealed that $\mathrm{CD} 4^{+} \mathrm{CD} 69^{+} \mathrm{CD} 103^{+} \mathrm{T}_{\mathrm{RM}}$ are able to downregulate CD69 and egress from skin tissue. In a mouse xenograft model, these cells re-entered circulation and migrated to secondary human skin xenografts, where they again adopted a $\mathrm{T}_{\mathrm{RM}}$ phenotype [31]. These findings challenge the paradigm that $T_{R M}$ remain more or less permanently tethered within non-lymphoid tissues and suggest that under specific conditions, $\mathrm{T}_{\mathrm{RM}}$ are capable of migrating from one tissue site to another.

\section{What Pathways Promote $\mathrm{T}_{\mathrm{RM}}$ Development, Accumulation, and Survival?}

While the pathways that promote accumulation and long-term survival of $T_{R M}$ have not been fully elucidated, accumulation of $T_{R M}$ in the mouse small intestine and female reproductive tract may require signaling from the mammalian target of rapamycin (mTOR) kinase, a critical regulator of cell differentiation and survival $[22,23]$. Additionally, in a mouse model of cutaneous viral infection, long-term survival of $\mathrm{CD} 8^{+}$ $\mathrm{T}_{\mathrm{RM}}$ required expression of molecules mediating lipid uptake and transport, including fatty acid binding proteins 4 and 5 (FABP4 and 5) [24•]. Increased expression of these molecules was observed in $\mathrm{CD}^{+} \mathrm{T}$ cells from normal and psoriatic human skin [24•]. In addition to the transcription factors mentioned in the previous section, recent work has shown that transcription factor Runx 3 is also important for $T_{R M}$ maintenance and plays a role in their early differentiation $[15,25 \cdot]$.

The purinergic receptor P2RX7, a sensor for extracellular ATP, serves as a detector of cell injury and inflammation. Recent work in mouse models suggests that it also plays a role in supporting generation of long-lived $\mathrm{CD} 8^{+} \mathrm{T}_{\mathrm{RM}}$ by promoting mitochondrial homeostasis and metabolic function. Accordingly, extracellular ATP that is produced through cell activation and/or tissue damage may contribute to the development of T cell memory [26•].

The transcription factor Bhlhe 40 was shown to be required for the development and polyfunctionality of both $\mathrm{CD}^{+} \mathrm{T}_{\mathrm{RM}}$ and tumor-infiltrating lymphocytes (TILs), playing a role in mitochondrial fitness and epigenetic programming [27•]. Bhlhe40 (also known as Dec1, Stra13, Sharp2, and Bhlhb2) is expressed in T cells upon TCR stimulation, and mice lacking this factor develop a late-onset lymphoproliferative disease that may be related to a role for Bhlhe 40 in the maintenance of regulatory $\mathrm{T}$ cells $\left(\mathrm{T}_{\text {reg }}\right)$ during aging [32].
There appear to be tissue-specific requirements for $T_{R M}$ formation and maintenance: cognate antigen is apparently required for $\mathrm{T}_{\mathrm{RM}}$ establishment in brain and lung, but not in other tissues [33]. The role of TCR affinity in $\mathrm{T}_{\mathrm{RM}}$ formation may also depend upon tissue and context. In mouse polyomavirus infection, $\mathrm{T}_{\mathrm{RM}}$ residing in the brain and kidney were found to express TCRs with up to 20-fold higher affinity for their ligands than those of splenic memory T cells [34]. Higher affinity TCRs could facilitate detection of low levels of antigen in the early stages of infection or re-infection, allowing early clearance [34]. Interestingly, in studies designed to determine the impact of TCR signal strength on $T_{R M}$ formation during influenza A virus infection, lower-affinity ligands were more likely than higher-affinity stimulations to induce $T_{R M}$ in the mouse lung [35•]. Higher-affinity stimulations elicited a larger clonal burst size, leading to an increased total number of $\mathrm{T}_{\mathrm{RM}}$. Overall, TCR affinity did not impact the cell surface phenotype or long-term survival of lung $\mathrm{T}_{\mathrm{RM}}[35 \bullet]$.

\section{Of Mice and Men: Lessons from Rodent Models and Challenges for Studying Human $\mathbf{T}_{\mathrm{RM}}$}

The concept of tissue residency has been developed and refined thanks to careful experimentation in rodent models, recently reviewed in detail by others [1]. Briefly, four novel approaches have been used to elucidate $\mathrm{T}$ cell trafficking and residency in rodent tissues: parabiosis surgery, tissue transplantation, in situ labeling, and in vivo intravascular staining [1]. In parabiosis, mice carrying distinct genetic markers are surgically joined for a prolonged period, allowing blood vessels to interconnect or anastomose. Non-resident lymphocytes circulate through both animals, while tissue residents patrol a restricted area within a given tissue [36]. In transplantation, a single mouse receives a tissue or organ graft from a genetically distinct animal (in some cases a xenograft), and lymphocyte trafficking to and from the graft is examined. A third approach involves labeling specific cell types in situ; for example, transgenic cells may be engineered to express fluorescent proteins, and their migration (or retention) tracked. Fourth, dyes may be injected intravascularly and used to track cell $\mathrm{T}$ cell trafficking and recirculation patterns. Each of these approaches has caveats, but collectively, their use has contributed enormous insights to our understanding of lymphocyte biology and host defense [1].

Experimental approaches for studying human $\mathrm{T}_{\mathrm{RM}}$ are necessarily more limited. For logistical reasons, studies of human $\mathrm{T}_{\mathrm{RM}}$ have relied on indirect methods, such as multidimensional phenotyping and/or transcriptional profiling of $\mathrm{T}_{\mathrm{RM}}$ obtained from clinical study participants and in some cases organ donors $[9,11,18 \bullet \bullet, 37 \bullet, 38 \bullet, 39 \bullet \cdot]$. Important insights have also been gained from immunotherapy studies: $T_{R M}$ subsets in 
human skin were characterized in patients with cutaneous $\mathrm{T}$ cell lymphoma who received humanized anti-CD52 antibody (alemtuzumab). This antibody depletes circulating $\mathrm{CD}_{52}{ }^{+} \mathrm{T}$ cells but does not affect $\mathrm{T}_{\mathrm{RM}}[40,41]$. Allograft models, in which neonatal human foreskin samples are grafted onto mice, have also been exploited to examine $\mathrm{T}$ cell trafficking and residency [31, 41]. Another novel approach to sampling recirculating $\mathrm{T}$ cell populations involves collection of paired blood and thoracic duct lymph (TDL) samples from patients with clinical indications for thoracic duct cannulation [39••]. This technique has been used to study recirculation patterns of $\mathrm{T}$ follicular helper cells [42] and mucosa-associated invariant $\mathrm{T}$ cells (MAIT) [43], as well as to establish trafficking and residency patterns of $\mathrm{T}_{\mathrm{RM}}[39 \bullet \bullet]$.

An important cautionary note regarding methodology was raised by a study comparing two approaches to $T_{\mathrm{RM}}$ quantitation: enzymatic digestion to isolate lymphocytes from the tissue matrix, followed by flow cytometry, versus quantitative immunofluorescence microscopy (QIM) of serial tissue sections [17]. Findings revealed that single-cell suspensions successfully recovered only a minority of viable $\mathrm{T}$ cells, leading to an underestimate of $\mathrm{T}_{\mathrm{RM}}$ and distorted estimates of their distribution and phenotype. This report, coupled with an earlier study utilizing human gastrointestinal biopsy tissues [44], serves as a reminder that over-reliance on a single experimental approach may be misleading.

\section{Roles for $T_{R M}$ in Host Defense Against Viral Pathogens}

Experiments in mice using the approaches described above point to a key role for $\mathrm{T}_{\mathrm{RM}}$ in limiting viral dissemination and tissue damage in several key models, notably herpes simplex virus (HSV) and lymphocytic choriomeningitis virus (LCMV) infections. Three critical functions appear to be characteristic of $\mathrm{T}_{\mathrm{RM}}$ : rapid proliferation and expansion in situ [33, $45 \bullet, 46 \bullet$, cytotoxicity [47••, 48•], and an innate-like "sense and alarm" response $[49,50]$. Notably, this sense and alarm function is credited with amplifying the immune response by activating both bystander $\mathrm{T}_{\mathrm{RM}}$ and other local immune cells and may explain how infection can be controlled despite a relatively low initial ratio of virus-specific $T_{\mathrm{RM}}$ to infected target cells $[49,50]$. But what is the evidence that $T_{R M}$ play a major role in containing or clearing human viral pathogens? Published studies describe or imply a role for $\mathrm{T}_{\mathrm{RM}}$ in nearly 30 infectious diseases relevant to humans [51]. In HSV-2, repeated sampling of human genital mucosa, coupled with mathematical modeling, has suggested a role for $\mathrm{CD}^{+} \mathrm{T}_{\mathrm{RM}}$ in limiting the duration of viral replication episodes [36, 52, 53]. In respiratory syncytial virus (RSV) infection, $\mathrm{CD}^{+} \mathrm{T}_{\mathrm{RM}}$ accumulate to high frequencies in the lungs, where they may be collected by bronchoalveolar lavage (BAL). In healthy adult volunteers experimentally inoculated with RSV, the frequency of RSV-specific $\mathrm{CD}^{+} \mathrm{T}$ cells in BAL at baseline did not correlate with susceptibility to infection [54]. However, higher frequencies were associated with lower cumulative symptom scores and viral loads, suggesting that $\mathrm{CD}^{+} \mathrm{T}_{\mathrm{RM}}$ play a role in limiting and/or clearing RSV infection when present near the sites of viral replication [54]. The RSV model is potentially informative for other mucosal infections, because it represents a disease in which antibody, in this case locally produced mucosal IgA, forms an initial barrier to infection, but does not limit disease severity once that barrier has been crossed [54, 55]. In this context, $\mathrm{CD} 8^{+} \mathrm{T}_{\mathrm{RM}}$ form a second line of defense that helps reduce viral load and disease severity.

\section{Human $T_{R M}$ and HIV Infection}

$\mathrm{T}_{\mathrm{RM}}$ are primarily conceptualized as residing in non-lymphoid tissues (NLT) such as the lung, liver, gut, and skin; in addition, some $\mathrm{T}_{\mathrm{RM}}$ are present in lymphoid tissues (LT), such as the lymph nodes and spleen [17, 39••]. Many of these tissues are difficult or impossible to access and study in human volunteers; accordingly, studies of $\mathrm{T}_{\mathrm{RM}}$ in HIV-infected persons to date have been relatively limited. However, a large amount of information on human $\mathrm{T}_{\mathrm{RM}}$ has been generated from a series of comprehensive studies performed on tissues accessed from organ donors [9-11, 56, 57]. This work addressed the distribution patterns and phenotypes of human $\mathrm{CD}^{+}$and $\mathrm{CD}^{+}$ memory T cells from the blood, spleen, lung, and gastrointestinal mucosa as well as mesenteric, inguinal, and lung lymph nodes [9-11, 56, 57]. Numerous memory cells $(>80 \%)$ in lymph nodes and spleen expressed CD69, unlike circulating memory T cells in blood [9]. CD103 expression, however, was primarily limited to memory cells in mucosal tissues, particularly the gut [9]. Interestingly, mouse memory $\mathrm{T}$ cells in the spleen and LN are reportedly CD69 ${ }^{\text {low }}$, pointing to another potential difference in $\mathrm{T}_{\mathrm{RM}}$ between species [5].

In a comprehensive study comparing HIV-specific $\mathrm{CD}^{+} \mathrm{T}$ cells from blood, thoracic duct lymph (TDL), and lymph nodes (LN), Buggert and colleagues tested whether HIVspecific CD8+ T cells with transcriptional and epigenetic signatures typical of $\mathrm{T}_{\mathrm{RM}}$ were present in HIV-infected LN [39••]. They found that HIV-specific, $\mathrm{CD} 69^{+}$memory $\mathrm{CD} 8^{+}$ $\mathrm{T}$ cells were significantly expanded in LN of HIV-positive individuals. These cells were mainly $\mathrm{Ki} 7^{\text {neg }}$ and therefore not actively proliferating, but bore epigenetic and transcriptional signatures of $\mathrm{T}_{\mathrm{RM}}$. Comparatively high frequencies of HIV-specific $\mathrm{T}_{\mathrm{RM}}$ were present in $\mathrm{LN}$ of elite controllers. Single-cell RNAseq revealed that HIV-specific, CD69 ${ }^{+} \mathrm{T}_{\mathrm{RM}}$ from $\mathrm{LN}$ were enriched for effector-related genes relative to HIV-specific, $\mathrm{CD} 9^{\text {neg }}$ non- $\mathrm{T}_{\mathrm{RM}}$ from $\mathrm{LN}$ of the same individuals $[39 \bullet \bullet]$. This finding was particularly intriguing given that earlier work from the same group demonstrated more 
limited cytotoxic capacity of $\mathrm{CD} 8^{+} \mathrm{T}$ cells from lymph node (i.e., not separated based on 69 expression) compared with those from blood [47••].

Kiniry and colleagues identified $\mathrm{CD} 8^{+} \mathrm{T}$ cells with a Tbet $^{\text {Low }} /$ Eomes $^{\mathrm{Neg}}$ phenotype in colorectal mucosa of HIVpositive individuals [48•]. Perforin expression and ex vivo cytolytic capacity were significantly reduced in these cells compared to their counterparts in blood, regardless of HIV clinical status. Although these T-bet ${ }^{\text {Low }} /$ Eomes $^{\mathrm{Neg}} \mathrm{CD} 8^{+} \mathrm{T}$ cells were abundant in colorectal mucosa of HIV controllers, neither perforin expression nor cytolytic capacity was elevated in controllers compared to other participant groups; however, these cells did express multiple cytokines/chemokines in response to TCR stimulation [48•]. This T-bet ${ }^{\mathrm{Low}} / \mathrm{Eomes}^{\mathrm{Neg}}$ phenotype was similar to that described for $\mathrm{CD} 8^{+}$memory $\mathrm{T}$ cells in LN, which were also described as weakly cytolytic compared to blood $\mathrm{CD} 8^{+} \mathrm{T}$ cells [47••]. In subsequent work, Kiniry and colleagues identified HIV-specific $\mathrm{CD} 8^{+} \mathrm{T}$ cells with both $\mathrm{T}_{\mathrm{RM}}$ and resident effector $\left(\mathrm{rT}_{\mathrm{EFF}}\right)$ phenotypes [38 $]$. Both populations included polyfunctional cells that degranulated and produced MIP- $1 \beta$, IFN- $\gamma$, and in some cases TNF- $\alpha$ in response to TCR stimulation [38•]. Taken together, and in view of other earlier work [58-60], these studies suggest that regulatory programs favoring cytokine/ chemokine expression, rather than maximizing cytolytic capacity, may be favored in the tissue microenvironments where $\mathrm{T}_{\mathrm{RM}}$ reside $[38 \bullet, 47 \bullet \bullet, 48 \bullet]$.

\section{Resident Memory T Cells Are an HIV Reservoir in the Female Reproductive Tract}

Although many studies have focused on tissue reservoirs for HIV/SIV infection, notably in lymphoid tissues and the gastrointestinal tract $([61 \bullet, 62]$ and references therein), there have been limited studies focused on the female reproductive tract (FRT) as an HIV reservoir. From previous work, the cell surface phenotype and activation status of $\mathrm{CD}^{+} \mathrm{T}$ cells throughout the FRT suggested high susceptibility to HIV infection, as did in vitro infection studies [63•]. Studying paired blood and cervical samples from $8 \mathrm{HIV}$-infected women who had been cART-suppressed for at least 1 year, Centero-Perez and colleagues found that cervical $\mathrm{T}$ cells contained up to $>200$-fold more HIV proviral DNA per cell compared to blood T cells [63•]. Within cervical $\mathrm{CD}^{+/-} \mathrm{T}$ cells, $>80 \%$ were defined as $\mathrm{T}_{\mathrm{RM}}$ based on CD69 expression, and this population contributed $>95 \%$ of the HIV DNA-positive cells in cervix [63 ${ }^{\circ}$. Cervical $\mathrm{T}_{\mathrm{RM}}$ also contained transcriptionally active HIV; however, due to cell number limitations, quantitative viral growth assays could not be performed. This study identifies cervical $\mathrm{CD} 4^{+} \mathrm{T}_{\mathrm{RM}}$ as a potential target for HIV eradication efforts.

\section{A Novel Approach to HIV Reservoir Eradication}

Despite the success of combination antiretroviral therapy (cART), complete eradication of virus from tissue sanctuaries remains a daunting and elusive technical challenge. A large body of work has demonstrated that HIV-infected $\mathrm{CD}^{+}$follicular helper T cells (Tfh) localized within LN B cell follicles constitute a major viral reservoir in both viremic and cARTtreated individuals $[64,65]$. $\mathrm{CD} 8^{+} \mathrm{T}$ cells are typically excluded from B cell follicles, since most lack expression of CXCR5, which directs germinal center homing. Fingolimod (FTY720), a drug approved by the US Food and Drug Administration (FDA) for treatment of multiple sclerosis, blocks T cell egress from LN by preventing interaction of sphingosine-1-phosphate (S1P) with four of its receptors (S1PR1, 3, 4, and 5), essentially depriving the T cells of lymph node "exit visas" [66]. As mentioned previously, transcriptional downregulation of S1PR1 is required for establishment of $\mathrm{CD} 8^{+} \mathrm{T}_{\mathrm{RM}}$ [67]. In a recent study, FTY720 was administered to rhesus macaques infected with simian immunodeficiency virus (SIVmac) with viral suppression following cART [61•]. FTY720 treatment reduced circulating $\mathrm{CD}^{+}$and $\mathrm{CD} 8^{+} \mathrm{T}$ cells in a dose-dependent manner, increasing the number of potentially cytolytic $\mathrm{T}$ cells in $\mathrm{LN}$ and leading to decreased SIV DNA in blood and LN of most treated animals. Although the effects of this treatment on $T_{R M}$ in nonlymphoid tissues were not addressed, this work demonstrates the feasibility of modulating $\mathrm{T}$ cell trafficking through interference with S1P/S1PR interactions, potentially helping eradicate formerly intractable HIV reservoirs.

\section{Vaccine Induction of $\mathrm{T}_{\mathrm{RM}}$ in HIV Models}

Although recent HIV vaccine development efforts have focused largely on eliciting neutralizing antibodies, anything less than completely "sterilizing" immunological protection will necessitate one or more mechanisms of clearing foci of infection at or near the site of exposure. For this reason, vaccines that stimulate multiple immune effector mechanisms, particularly within mucosal tissues, may have a greater likelihood of success than those focused solely on antibodies. Several authors have argued persuasively for development of HIV vaccines capable of eliciting $\mathrm{CD} 8^{+} \mathrm{T}$ cell immunity [68-70]. Multiple lines of evidence support this reasoning, including the following: (i) strong correlations between HIVspecific $\mathrm{CD}^{+} \mathrm{T}$ cell function and elite controller status [71]; (ii) success of therapeutic Ad26/MVA vaccination combined with TLR7 stimulation in targeting SIV reservoirs in rhesus macaques [72]; (iii) promising results in vaccine trials using vectors based on cytomegalovirus (CMV) [73, 74], adenoviruses, and Modified Virus Ankara (MVA) that elicit T cell responses. However, to date, few vaccine studies in humans 
have included the type of mucosal sampling that would allow quantification of antigen-specific tissue resident $\mathrm{T}$ cells near the sites of potential HIV exposure. Furthermore, when such sampling has occurred, $\mathrm{T}_{\mathrm{RM}}$ markers have generally not been assessed, although this is anticipated to change as the $T_{R M}$ literature expands.

Heterologous viral vectors may be combined to elicit particular combinations of $\mathrm{T}$ cell and antibody responses. Recently, Petitdemange and colleagues tested the hypothesis that vaccine preparations capable of eliciting both highmagnitude $\mathrm{CD} 8^{+} \mathrm{T}$ cell responses and antibodies would confer enhanced protection to rhesus macaques against low-dose intravaginal challenge with heterologous SHIV [75•]. Female macaques were immunized with one of three regimens, designed to elicit either strong $\mathrm{T}$ cell responses (group 1), antibodies (group 2), or both (group 3). Examination of tissues revealed impressive numbers and frequencies of SIVspecific, MHC class I tetramer-binding $\mathrm{CD} 8^{+} \mathrm{T}$ cells in blood, iliac lymph nodes, and reproductive tissues post-vaccination. Although long-term protection was not observed after 10 challenges, near-significant protection was detected after 5 challenges in groups 2 and 3 and correlated with magnitude of serum and vaginal Env-specific antibody titers on the day of challenge [75•]. Intriguingly, despite similar antibody titers, enhanced protection was observed in younger animals $(<$ 8 years) that received immunogens eliciting both $\mathrm{T}$ cell and antibody responses (i.e., group 3). Thus, although protection was modest, this model argues for vaccines capable of stimulating both humoral and cell-mediated immunity.

\section{Conclusions}

The literature cited in this review indicates an increasing focus on the role of tissue-based immune responses in the host response to infectious disease. In the past, prior to the discovery of $\mathrm{T}_{\mathrm{RM}}$, there was an implicit assumption of a direct relationship between immune responses measured in peripheral blood and those present in tissues throughout the body. However, as illustrated by the studies cited in this review, blood sampling can underestimate, and at times fundamentally misrepresent, $\mathrm{T}$ cell responses at the site of infection. $\mathrm{T}_{\mathrm{RM}}$ differ from their counterparts in blood not only in quantity and cell surface phenotype but also in transcriptional programming and functionality, such that attempts to predict or extrapolate $T_{R M}$ responses from blood samples alone ignore critical information.

In addition to their obvious relevance to HIV and other infectious diseases, $T_{R M}$ appear to play a role in the pathogenesis of certain inflammatory and autoimmune conditions. Among the best studied to date are skin conditions including allergic contact dermatitis, psoriasis, and fixed drug eruption, as well as vitiligo and Sézary syndrome (for review, see [76]). In addition, there may be a role for $\mathrm{T}_{\mathrm{RM}}$ in the pathogenesis of gastrointestinal diseases such as Crohn's disease and/or ulcerative colitis and in joint diseases such as ankylosing spondylitis and rheumatoid arthritis [76]. In human cancer, tumorinfiltrating lymphocytes (TIL) are speculated to be a form of $\mathrm{T}_{\mathrm{RM}}$, and their ability to infiltrate solid tumors has been described as a favorable prognostic indicator in certain bladder, breast, cervical, endometrial, lung, and ovarian cancers [77]. Expression of adhesion molecules such as CD103 may help facilitate $T_{R M}$ lodgment within solid tumors [77]. $T_{R M}$ also have a metabolic advantage that could favor their persistence in a low-glucose tumor microenvironment: $T_{R M}$ preferentially take up and catabolize free fatty acids due to their expression of transporters FABP4 and 5. However, this advantage is limited by the requirement of fatty acid catabolism for oxygendependent respiration [77].

In conclusion, recent literature has implicated $\mathrm{T}_{\mathrm{RM}}$ as critical tissue defenders in multiple contexts including HIV, other infectious diseases, and cancer. These studies provide exciting avenues for future development of more effective vaccines and immunotherapeutics.

Acknowledgments The authors thank colleagues and collaborators at the University of California, Davis and the University of California, San Francisco for helpful critical discussions. We are indebted to our study participants for their willingness to contribute samples to our research.

Funding Information The authors' work is funded by National Institutes of Health (NIH) grants R01-AI057020 and R01-DK108350, the Bill and Melinda Gates Foundation, the James B. Pendleton Charitable Trust, and contracts from Gilead Sciences.

\section{Compliance with Ethical Standards}

Conflict of Interest In addition to the funding sources acknowledged above, during the past year, Dr. Shacklett acted as a Consultant for Merck, Sharp \& Dohme. The authors report no conflict of interest that could be interpreted to influence this work.

Human and Animal Rights All reported studies/experiments with human or animal subjects performed by the authors have been previously published and complied with all applicable ethical standards (including the Helsinki declaration and its amendments, institutional/national research committee standards, and international/national/institutional guidelines).

Open Access This article is licensed under a Creative Commons Attribution 4.0 International License, which permits use, sharing, adaptation, distribution and reproduction in any medium or format, as long as you give appropriate credit to the original author(s) and the source, provide a link to the Creative Commons licence, and indicate if changes were made. The images or other third party material in this article are included in the article's Creative Commons licence, unless indicated otherwise in a credit line to the material. If material is not included in the article's Creative Commons licence and your intended use is not permitted by statutory regulation or exceeds the permitted use, you will need to obtain permission directly from the copyright holder. To view a copy of this licence, visit http://creativecommons.org/licenses/by/4.0/. 


\section{References}

Papers of particular interest, published recently, have been highlighted as:

- Of importance

•- Of major importance

1. Masopust D, Soerens AG. Tissue-resident T cells and other resident leukocytes. Annu Rev Immunol. 2019;37:521-46. https://doi.org/ 10.1146/annurev-immunol-042617-053214.

2. Gowans JL. The life-history of lymphocytes. Br Med Bull. 1959;15(1):50-3. https://doi.org/10.1093/oxfordjournals.bmb. a069715.

3. Sallusto F, Lenig D, Forster R, Lipp M, Lanzavecchia A. Two subsets of memory $\mathrm{T}$ lymphocytes with distinct homing potentials and effector functions. Nature. 1999;401(6754):708-12. https://doi. org/10.1038/44385.

4. Carbone FR, Mackay LK, Heath WR, Gebhardt T. Distinct resident and recirculating memory $\mathrm{T}$ cell subsets in non-lymphoid tissues. Curr Opin Immunol. 2013;25(3):329-33. https://doi.org/10.1016/j. coi.2013.05.007.

5. Casey KA, Fraser KA, Schenkel JM, Moran A, Abt MC, Beura LK, et al. Antigen-independent differentiation and maintenance of effector-like resident memory $\mathrm{T}$ cells in tissues. J Immunol. 2012;188(10):4866-75. https://doi.org/10.4049/jimmunol. 1200402 .

6. Gebhardt T, Wakim LM, Eidsmo L, Reading PC, Heath WR, Carbone FR. Memory T cells in nonlymphoid tissue that provide enhanced local immunity during infection with herpes simplex virus. Nat Immunol. 2009;10(5):524-30. https://doi.org/10.1038/ni. 1718.

7. Mackay LK, Stock AT, Ma JZ, Jones CM, Kent SJ, Mueller SN, et al. Long-lived epithelial immunity by tissue-resident memory $\mathrm{T}$ (TRM) cells in the absence of persisting local antigen presentation. Proc Natl Acad Sci U S A. 2012;109(18):7037-42. https://doi.org/ 10.1073/pnas.1202288109.

8. Masopust D, Choo D, Vezys V, Wherry EJ, Duraiswamy J, Akondy $\mathrm{R}$, et al. Dynamic T cell migration program provides resident memory within intestinal epithelium. J Exp Med. 2010;207(3):553-64. https://doi.org/10.1084/jem.20090858.

9. Sathaliyawala T, Kubota M, Yudanin N, Turner D, Camp P, Thome $\mathrm{JJ}$, et al. Distribution and compartmentalization of human circulating and tissue-resident memory $\mathrm{T}$ cell subsets. Immunity. 2013;38(1):187-97. https://doi.org/10.1016/j.immuni.2012.09. 020.

10. Thome JJ, Farber DL. Emerging concepts in tissue-resident T cells: lessons from humans. Trends Immunol. 2015;36(7):428-35. https://doi.org/10.1016/j.it.2015.05.003.

11. Kumar BV, Connors TJ, Farber DL. Human T cell development, localization, and function throughout life. Immunity. 2018;48(2): 202-13. https://doi.org/10.1016/j.immuni.2018.01.007.

12. Farber DL. Training T cells for tissue residence. Science. 2019;366(6462):188-9. https://doi.org/10.1126/science.aaz3289.

13. Szabo PA, Miron M, Farber DL. Location, location, location: tissue resident memory $\mathrm{T}$ cells in mice and humans. Sci Immunol. 2019;4(34). https://doi.org/10.1126/sciimmunol.aas9673.

14. Mackay LK, Kallies A. Transcriptional regulation of tissue-resident lymphocytes. Trends Immunol. 2017;38(2):94-103. https://doi.org/ 10.1016/j.it.2016.11.004.

15. Milner JJ, Goldrath AW. Transcriptional programming of tissueresident memory CD8(+) T cells. Curr Opin Immunol. 2018;51: 162-9. https://doi.org/10.1016/j.coi.2018.03.017.

16. Walsh DA, Borges da Silva H, Beura LK, Peng C, Hamilton SE, Masopust D et al. The functional requirement for CD69 in establishment of resident memory CD8(+) T cells varies with tissue location. J Immunol 2019;203(4):946-955. doi:https://doi.org/10. 4049/jimmunol.1900052.

17. Steinert EM, Schenkel JM, Fraser KA, Beura LK, Manlove LS, Igyarto BZ, et al. Quantifying memory CD8 T cells reveals regionalization of immunosurveillance. Cell. 2015;161(4):737-49. https://doi.org/10.1016/j.cell.2015.03.031.

18.• Kumar BV, Ma W, Miron M, Granot T, Guyer RS, Carpenter DJ, et al. Human tissue-resident memory $\mathrm{T}$ cells are defined by core transcriptional and functional signatures in lymphoid and mucosal sites. Cell Rep. 2017;20(12):2921-34. https://doi.org/10.1016/j. celrep.2017.08.078 This paper identifies a core transcriptional profile that defines $T_{R M}$ in human tissues, based on homology to the reported profile of mouse $T_{R M}$.

19. Bankovich AJ, Shiow LR, Cyster JG. CD69 suppresses sphingosine 1-phosophate receptor-1 (S1P1) function through interaction with membrane helix 4. J Biol Chem. 2010;285(29):22328-37. https://doi.org/10.1074/jbc.M110.123299.

20. Mackay LK, Wynne-Jones E, Freestone D, Pellicci DG, Mielke LA, Newman DM, et al. T-box transcription factors combine with the cytokines TGF-beta and IL-15 to control tissue-resident memory T cell fate. Immunity. 2015;43(6):1101-11. https://doi.org/10. 1016/j.immuni.2015.11.008.

21. Mackay LK, Minnich M, Kragten NA, Liao Y, Nota B, Seillet C, et al. Hobit and Blimp1 instruct a universal transcriptional program of tissue residency in lymphocytes. Science. 2016;352(6284):459 63. https://doi.org/10.1126/science.aad2035.

22. Sowell RT, Marzo AL. Resident-memory CD8 T cells and mTOR: generation, protection, and clinical importance. Front Immunol. 2015;6:38. https://doi.org/10.3389/fimmu.2015.00038.

23. Sowell RT, Rogozinska M, Nelson CE, Vezys V, Marzo AL. Cutting edge: generation of effector cells that localize to mucosal tissues and form resident memory CD8 T cells is controlled by mTOR. J Immunol. 2014;193(5):2067-71. https://doi.org/10. 4049/jimmunol.1400074.

24. Pan Y, Tian T, Park CO, Lofftus SY, Mei S, Liu X, et al. Survival of tissue-resident memory $T$ cells requires exogenous lipid uptake and metabolism. Nature. 2017;543(7644):252-6. https://doi.org/10. 1038/nature21379 This study demonstrates that mouse $\mathbf{T}_{\mathbf{R M}}$ express high levels of molecules that mediate lipid uptake, including fatty acid binding proteins 4 and 5 (FAPB4 and 5).

25. Milner JJ, Toma C, Yu B, Zhang K, Omilusik K, Phan AT, et al. Runx3 programs CD8(+) T cell residency in non-lymphoid tissues and tumours. Nature. 2017;552(7684):253-7. https://doi.org/10. 1038/nature24993 This paper identifies transcription factor Runx 3 as a key regulator of $T_{R M}$ differentiation and homeostasis and demonstrates that in mice, Runx3-deficient melanoma-infiltrating lymphocytes fail to accumulate in tumors.

26. Borges da Silva H, Beura LK, Wang H, Hanse EA, Gore R, Scott $\mathrm{MC}$, et al. The purinergic receptor P2RX7 directs metabolic fitness of long-lived memory CD8(+) T cells. Nature. 2018;559(7713): 264-8. https://doi.org/10.1038/s41586-018-0282-0 This paper demonstrates that $\mathrm{P} 2 \mathrm{RX} 7$ promotes homeostasis and metabolic function in $\mathrm{CD8}^{+} \mathrm{T}_{\mathrm{RM}}$ in mice.

27. Li C, Zhu B, Son YM, Wang Z, Jiang L, Xiang M, et al. The transcription factor Bhlhe40 programs mitochondrial regulation of resident $\mathrm{CD} 8(+) \mathrm{T}$ cell fitness and functionality. Immunity. 2019;51(3):491-507 e7. https://doi.org/10.1016/j.immuni.2019. 08.013 This report shows that transcription factor Bhlhe40 is required for both $T_{R M}$ and TIL development and polyfunctionality in mice.

28. Mueller SN, Mackay LK. Tissue-resident memory T cells: local specialists in immune defence. Nat Rev Immunol. 2016;16(2):79 89. https://doi.org/10.1038/nri.2015.3. 
29. Mani V, Bromley SK, Aijo T, Mora-Buch R, Carrizosa E, Warner $\mathrm{RD}$ et al. Migratory DCs activate TGF-beta to precondition naive CD8(+) T cells for tissue-resident memory fate. Science. 2019;366(6462). https://doi.org/10.1126/science.aav5728. This report describes a process in which naive $\mathbf{T}$ cells interact with migratory dendritic cells within lymph nodes, "conditioning" the $\mathbf{T}$ cells for a specialized memory differentiation fate.

30. Kumar BV, Kratchmarov R, Miron M, Carpenter DJ, Senda T, Lerner $\mathrm{H}$, et al. Functional heterogeneity of human tissue-resident memory $\mathrm{T}$ cells based on dye efflux capacities. JCI Insight. 2018;3(22). https://doi.org/10.1172/jci.insight.123568 This report identifies subpopulations of human $T_{R M}$, with different proliferative capacities and signaling patterns, based upon the ability to efflux fluorescent dyes.

31. Klicznik MM, Morawski PA, Hollbacher B, Varkhande SR, Motley SJ, Kuri-Cervantes L, et al. Human CD4(+)CD103(+) cutaneous resident memory $\mathrm{T}$ cells are found in the circulation of healthy individuals. Sci Immunol. 2019;4(37). https://doi.org/10.1126/ sciimmunol.aav8995.

32. Lin CC, Bradstreet TR, Schwarzkopf EA, Sim J, Carrero JA, Chou $\mathrm{C}$, et al. Bhlhe 40 controls cytokine production by $\mathrm{T}$ cells and is essential for pathogenicity in autoimmune neuroinflammation. Nat Commun. 2014;5:3551. https://doi.org/10.1038/ncomms4551.

33. Low JS, Kaech SM. Trials and Tribble-ations of tissue TRM cells. Nat Immunol. 2018;19(2):102-3. https://doi.org/10.1038/s41590017-0031-9.

34. Frost EL, Kersh AE, Evavold BD, Lukacher AE. Cutting edge: resident memory CD8 T cells express high-affinity TCRs. J Immunol. 2015;195(8):3520-4. https://doi.org/10.4049/jimmunol. 1501521.

35. Fiege JK, Stone IA, Fay EJ, Markman MW, Wijeyesinghe S, Macchietto MG, et al. The impact of TCR signal strength on resident memory $\mathrm{T}$ cell formation during influenza virus infection. $\mathrm{J}$ Immunol. 2019;203(4):936-45. https://doi.org/10.4049/jimmunol. 1900093 This report demonstrates that $\mathbf{T}_{\mathbf{R M}}$ formation is negatively correlated with increased TCR signal strength in the mouse lung after influenza $A$ infection.

36. Schiffer JT, Swan DA, Prlic M, Lund JM. Herpes simplex virus-2 dynamics as a probe to measure the extremely rapid and spatially localized tissue-resident T-cell response. Immunol Rev. 2018;285(1):113-33. https://doi.org/10.1111/imr.12672.

37. Senda T, Dogra P, Granot T, Furuhashi K, Snyder ME, Carpenter DJ, et al. Microanatomical dissection of human intestinal T-cell immunity reveals site-specific changes in gut-associated lymphoid tissues over life. Mucosal Immunol. 2019;12(2):378-89. https:// doi.org/10.1038/s41385-018-0110-8 This paper presents an extraordinarily detailed analysis of $T$ cell localization and phenotype throughout the human GI tract compiled from over 60 donors spanning 8 decades of life.

38. Kiniry BE, Li S, Ganesh A, Hunt PW, Somsouk M, Skinner PJ, et al. Detection of HIV-1-specific gastrointestinal tissue resident CD8(+) T-cells in chronic infection. Mucosal Immunol. 2018;11(3):909-20. https://doi.org/10.1038/mi.2017.96 This report explores the abundance, phenotype, and effector functions of gastrointestinal HIV-specific $T_{R M}$ in individuals with chronic HIV infection.

39.• Buggert M, Nguyen S, Salgado-Montes de Oca G, Bengsch B, Darko S, Ransier A, et al. Identification and characterization of HIV-specific resident memory CD8(+) T cells in human lymphoid tissue. Sci Immunol. 2018;3(24). https://doi.org/10.1126/ sciimmunol.aar4526 This paper demonstrates that HIV-specific $T_{R M}$ are present in human lymphoid tissues and compare transcriptional signatures of $T_{R M}$ to their counterparts in blood and thoracic duct lymph.

40. Clark RA, Watanabe R, Teague JE, Schlapbach C, Tawa MC, Adams N, et al. Skin effector memory T cells do not recirculate and provide immune protection in alemtuzumab-treated CTCL patients. Sci Transl Med. 2012;4(117):117ra7. https://doi.org/10. 1126/scitranslmed.3003008.

41. Watanabe R, Gehad A, Yang C, Scott LL, Teague JE, Schlapbach $\mathrm{C}$, et al. Human skin is protected by four functionally and phenotypically discrete populations of resident and recirculating memory T cells. Sci Transl Med. 2015;7(279):279ra39. https://doi.org/10. 1126/scitranslmed.3010302.

42. Vella LA, Buggert M, Manne S, Herati RS, Sayin I, Kuri-Cervantes $\mathrm{L}$, et al. T follicular helper cells in human efferent lymph retain lymphoid characteristics. J Clin Invest. 2019;129(8):3185-200. https://doi.org/10.1172/JCI125628.

43. Voillet V, Buggert M, Slichter CK, Berkson JD, Mair F, Addison $\mathrm{MM}$, et al. Human MAIT cells exit peripheral tissues and recirculate via lymph in steady state conditions. JCI Insight. 2018;3(7). https:// doi.org/10.1172/jci.insight.98487.

44. Preza GC, Yang OO, Elliott J, Anton PA, Ochoa MT. T lymphocyte density and distribution in human colorectal mucosa, and inefficiency of current cell isolation protocols. PLoS One. 2015;10(4): e0122723. https://doi.org/10.1371/journal.pone.0122723.

45. Park SL, Zaid A, Hor JL, Christo SN, Prier JE, Davies B, et al. Local proliferation maintains a stable pool of tissue-resident memory $\mathrm{T}$ cells after antiviral recall responses. Nat Immunol. 2018;19(2):183-91. https://doi.org/10.1038/s41590-017-0027-5 This study reports that in a mouse model, skin $\mathbf{T}_{\mathrm{RM}}$ proliferate in situ, respond to local antigen encounter, and do not leave the epidermis.

46. Beura LK, Mitchell JS, Thompson EA, Schenkel JM, Mohammed $\mathrm{J}$, Wijeyesinghe $\mathrm{S}$, et al. Intravital mucosal imaging of CD8(+) resident memory $\mathrm{T}$ cells shows tissue-autonomous recall responses that amplify secondary memory. Nat Immunol. 2018;19(2):173-82. https://doi.org/10.1038/s41590-017-0029-3 This study uses twophoto intravital microscopy to study $\mathbf{T}_{\mathrm{RM}}$ in the reproductive mucosa of live mice, showing that the cells undergo proliferation in situ and do not exit into the circulation.

47.• Reuter MA, Del Rio Estrada PM, Buggert M, Petrovas C, FerrandoMartinez S, Nguyen S, et al. HIV-specific CD8(+) T cells exhibit reduced and differentially regulated cytolytic activity in lymphoid tissue. Cell Rep. 2017;21(12):3458-70. https://doi.org/10.1016/j. celrep.2017.11.075 This paper demonstrates that HIV-specific CD8+ $T$ cells from lymph nodes exhibit weak cytolytic activity relative to peripheral blood $\mathrm{CD8}^{+} \mathrm{T}$ cells, suggesting a state of immune privilege against cytolysis in lymphoid tissue.

48. Kiniry BE, Ganesh A, Critchfield JW, Hunt PW, Hecht FM, Somsouk M, et al. Predominance of weakly cytotoxic, Tbet(Low)Eomes(Neg) CD8(+) T-cells in human gastrointestinal mucosa: implications for HIV infection. Mucosal Immunol. 2017;10(4):1008-20. https://doi.org/10.1038/mi.2016.100 This paper demonstrates that $\mathrm{CDB}^{+} \mathrm{T}$ cells isolated from human colorectal mucosa are weakly cytotoxic compared to blood $\mathrm{CD8}^{+} \mathrm{T}$ cells and express low levels of T-bet, paralleling the findings of Reuter and colleagues in lymph node.

49. Ariotti S, Hogenbirk MA, Dijkgraaf FE, Visser LL, Hoekstra ME, Song JY, et al. T cell memory. Skin-resident memory CD8(+) T cells trigger a state of tissue-wide pathogen alert. Science. 2014;346(6205):101-5. https://doi.org/10.1126/science.1254803.

50. Schenkel JM, Fraser KA, Beura LK, Pauken KE, Vezys V, Masopust D. T cell memory. Resident memory CD8 T cells trigger protective innate and adaptive immune responses. Science. 2014;346(6205):98-101. https://doi.org/10.1126/science.1254536.

51. Muruganandah V, Sathkumara HD, Navarro S, Kupz A. A systematic review: the role of resident memory $\mathrm{T}$ cells in infectious diseases and their relevance for vaccine development. Front Immunol. 2018;9:1574. https://doi.org/10.3389/fimmu.2018.01574.

52. Posavad CM, Zhao L, Dong L, Jin L, Stevens CE, Magaret AS, et al. Enrichment of herpes simplex virus type 2 (HSV-2) reactive 
mucosal $\mathrm{T}$ cells in the human female genital tract. Mucosal Immunol. 2017;10(5):1259-69. https://doi.org/10.1038/mi.2016. 118.

53. Schiffer JT, Swan DA, Roychoudhury P, Lund JM, Prlic M, Zhu J, et al. A fixed spatial structure of CD8(+) T cells in tissue during chronic HSV-2 infection. J Immunol. 2018;201(5):1522-35. https://doi.org/10.4049/jimmunol.1800471.

54. Jozwik A, Habibi MS, Paras A, Zhu J, Guvenel A, Dhariwal J, et al. RSV-specific airway resident memory CD8+ T cells and differential disease severity after experimental human infection. Nat Commun. 2015;6:10224. https://doi.org/10.1038/ncomms10224.

55. Habibi MS, Jozwik A, Makris S, Dunning J, Paras A, DeVincenzo JP, et al. Impaired antibody-mediated protection and defective IgA B-cell memory in experimental infection of adults with respiratory syncytial virus. Am J Respir Crit Care Med. 2015;191(9):1040-9. https://doi.org/10.1164/rccm.201412-2256OC.

56. Carpenter DJ, Granot T, Matsuoka N, Senda T, Kumar BV, Thome JJC, et al. Human immunology studies using organ donors: impact of clinical variations on immune parameters in tissues and circulation. Am J Transplant. 2018;18(1):74-88. https://doi.org/10.1111/ ajt.14434.

57. Thome JJ, Yudanin N, Ohmura Y, Kubota M, Grinshpun B, Sathaliyawala T, et al. Spatial map of human T cell compartmentalization and maintenance over decades of life. Cell. 2014;159(4): 814-28. https://doi.org/10.1016/j.cell.2014.10.026.

58. Halle S, Keyser KA, Stahl FR, Busche A, Marquardt A, Zheng X, et al. In vivo killing capacity of cytotoxic $\mathrm{T}$ cells is limited and involves dynamic interactions and $\mathrm{T}$ cell cooperativity. Immunity. 2016;44(2):233-45. https://doi.org/10.1016/j.immuni.2016.01. 010.

59. Andersson J, Kinloch S, Sonnerborg A, Nilsson J, Fehniger TE, Spetz AL, et al. Low levels of perforin expression in CD8+ T lymphocyte granules in lymphoid tissue during acute human immunodeficiency virus type 1 infection. J Infect Dis. 2002;185(9): 1355-8. https://doi.org/10.1086/340124.

60. Quigley MF, Abel K, Zuber B, Miller CJ, Sandberg JK, Shacklett BL. Perforin expression in the gastrointestinal mucosa is limited to acute simian immunodeficiency virus infection. J Virol. 2006;80(6):3083-7. https://doi.org/10.1128/JVI.80.6.3083-3087. 2006.

61. Pino M, Paganini S, Deleage C, Padhan K, Harper JL, King CT, et al. Fingolimod retains cytolytic $\mathrm{T}$ cells and limits $\mathrm{T}$ follicular helper cell infection in lymphoid sites of SIV persistence. PLoS Pathog. 2019;15(10):e1008081. https://doi.org/10.1371/journal. ppat.1008081 This paper tests a novel strategy designed to retain antiviral $T$ cells in lymphoid tissues in order to target viral reservoirs.

62. Telwatte S, Lee S, Somsouk M, Hatano H, Baker C, Kaiser P, et al. Gut and blood differ in constitutive blocks to HIV transcription, suggesting tissue-specific differences in the mechanisms that govern HIV latency. PLoS Pathog. 2018;14(11):e1007357. https://doi. org/10.1371/journal.ppat.1007357.

63. Cantero-Perez J, Grau-Exposito J, Serra-Peinado C, Rosero DA, Luque-Ballesteros L, Astorga-Gamaza A, et al. Resident memory $\mathrm{T}$ cells are a cellular reservoir for HIV in the cervical mucosa. Nat Commun. 2019;10(1):4739. https://doi.org/10.1038/s41467-01912732-2 This paper identifies CD4 ${ }^{+} \mathbf{T}$ cells in the lower female genital tract as a site of HIV persistence.

64. Fukazawa Y, Lum R, Okoye AA, Park H, Matsuda K, Bae JY, et al. $B$ cell follicle sanctuary permits persistent productive simian immunodeficiency virus infection in elite controllers. Nat Med. 2015;21(2):132-9. https://doi.org/10.1038/nm.3781.

65. Perreau M, Savoye AL, De Crignis E, Corpataux JM, Cubas R, Haddad EK, et al. Follicular helper T cells serve as the major CD4 T cell compartment for HIV-1 infection, replication, and production. J Exp Med. 2013;210(1):143-56. https://doi.org/10.1084/ jem.20121932.

66. Zajac AJ, Harrington LE. Tissue-resident T cells lose their S1P1 exit visas. Cell Mol Immunol. 2014;11(3):221-3. https://doi.org/10. 1038/cmi.2014.7.

67. Skon CN, Lee JY, Anderson KG, Masopust D, Hogquist KA, Jameson SC. Transcriptional downregulation of S1pr1 is required for the establishment of resident memory CD8+ T cells. Nat Immunol. 2013;14(12):1285-93. https://doi.org/10.1038/ni.2745.

68. Beura LK, Jameson SC, Masopust D. Is a human CD8 T-cell vaccine possible, and if so, what would it take? CD8 T-cell vaccines: to B or not to B? Cold Spring Harb Perspect Biol. 2018;10(9). https:// doi.org/10.1101/cshperspect.a028910.

69. McMichael AJ. Is a human CD8 T-cell vaccine possible, and if so, what would it take? Could a CD8(+) T-cell vaccine prevent persistent HIV infection? Cold Spring Harb Perspect Biol. 2018;10(9). https://doi.org/10.1101/cshperspect.a029124.

70. Wijesundara DK, Ranasinghe C, Grubor-Bauk B, Gowans EJ. Emerging targets for developing T cell-mediated vaccines for human immunodeficiency virus (HIV)-1. Front Microbiol. 2017;8: 2091. https://doi.org/10.3389/fmicb.2017.02091.

71. Jones RB, Walker BD. HIV-specific CD8(+) T cells and HIV eradication. J Clin Invest. 2016;126(2):455-63. https://doi.org/10.1172/ JCI80566.

72. Borducchi EN, Cabral C, Stephenson KE, Liu J, Abbink P, Ng'ang'a D, et al. Ad26/MVA therapeutic vaccination with TLR7 stimulation in SIV-infected rhesus monkeys. Nature. 2016;540(7632):284-7. https://doi.org/10.1038/nature20583.

73. Hansen SG, Ford JC, Lewis MS, Ventura AB, Hughes CM, CoyneJohnson L, et al. Profound early control of highly pathogenic SIV by an effector memory T-cell vaccine. Nature. 2011;473(7348): 523-7. https://doi.org/10.1038/nature10003.

74. Hansen SG, Zak DE, Xu G, Ford JC, Marshall EE, Malouli D, et al. Prevention of tuberculosis in rhesus macaques by a cytomegalovirus-based vaccine. Nat Med. 2018;24(2):130-43. https://doi.org/10.1038/nm.4473.

75. Petitdemange C, Kasturi SP, Kozlowski PA, Nabi R, Quarnstrom $\mathrm{CF}$, Reddy PBJ et al. Vaccine induction of antibodies and tissueresident $\mathrm{CD} 8+\mathrm{T}$ cells enhances protection against mucosal SHIVinfection in young macaques. JCI Insight. 2019;4(4). https://doi. org/10.1172/jci.insight.126047. This report describes vaccine regimens designed to elicit high levels of antibodies and/or $T_{R M}$. Although the approaches were only partially successful, there was enhanced protection in younger animals that received preparations eliciting both antibodies and $T_{R M}$.

76. Park CO, Kupper TS. The emerging role of resident memory T cells in protective immunity and inflammatory disease. Nat Med. 2015;21(7):688-97. https://doi.org/10.1038/nm.3883.

77. Amsen D, van Gisbergen K, Hombrink P, van Lier RAW. Tissueresident memory $\mathrm{T}$ cells at the center of immunity to solid tumors. Nat Immunol. 2018;19(6):538-46. https://doi.org/10.1038/s41590018-0114-2.

Publisher's Note Springer Nature remains neutral with regard to jurisdictional claims in published maps and institutional affiliations. 